\title{
Wildfire evidence from the Middle and Late Permian Hanxing Coalfield, North China Basin
}

\author{
$\begin{array}{lllll}\text { L. Xiao }^{1} & \text { Q. Zhao } & 1^{*} & \text { J. Wang } & \text { V. Mishra } \\ & \text { S.I. Arbuzov } & \text { M. Zhang }\end{array}$ \\ ${ }^{1}$ Key Laboratory of Resource Exploration Research of Hebei, Hebei University of Engineering \\ Handan 056038, Hebei, China. Xiao E-mail: xiaolin@hebeu.edu.cn, \\ Zhao E-mail: zhaoqiaojing@163.com \\ ${ }^{2}$ Hebei Collaborative Innovation Center of Coal Exploitation, Hebei University of Engineering \\ Handan 056038, Hebei, China. Wang E-mail: jinxi77@126.com, \\ Mishra E-mail: vmishrageology@gmail.com, Zhang E-mail: HUEZhangMM@126.com \\ ${ }^{3}$ Department of Geology and Geochemistry, Tomsk Polytechnic University \\ Tomsk area, Russia. Arbuzov E-mail: siarbuzov@mail.ru
}

${ }^{*}$ Corresponding author

A B S T R A C T

Earth has a long geological history and palaeo-wildfire is one of the key factors which is responsible for the evolution and extinction of our earth systems. The most important extinction of our earth systems is the PermianTriassic mass extinction. The objective of this paper is to evaluate the product of wildfire in terms of distribution and occurrences from the Late Permian North China basin. Fourteen rock samples were collected from a drill core of Hanxing Coalfield of North China basin. The samples were analyzed by macro and micro petrography, Scanning Electron Microscopy (SEM), Gas Chromatography (GC) and Gas Chromatography-Mass Spectrometry (GC-MS) in order to study the evidence of wildfire. Charcoal (inertinite) particles are observed in the samples, which established the occurrences of wildfire during the upper Middle and Late Permian time in North China. Additionally, high-molecular-weight Polycyclic Aromatic Hydrocarbons (PAHs) were detected in the studied samples which also reinforce the presence of palaeo-wildfire events in the North China basin in Late Permian due to the fact that these aromatic compounds were formed under high temperatures.

KEYWORDS Wildfire. Sedimentary rock. Permian. North China basin.

\section{INTRODUCTION}

Wildfire is a natural phenomenon since OrdovicianSilurian period when plants were introduced to the ecosystem. However, occurrences of wildfires are increasing in present days due to anthropogenic causes and the interrelationships between the wildfire and the future of mankind are coming into more light (Scott et al., 2016). Palaeo-wildfires are an important factor in the evolution of past climates, and therefore their study is relevant for the prediction of climate changes on earth (Flannigan et al., 2009; Freeman and Cattell, 1990; Grasby et al., 2011; Lenton, 2013; Scott and Glasspool, 2006; Shen et al., 2011; Sun et al., 2017; Yan et al., 2019; Xu et al., 2020a,

(C) L. Xiao, Q. Zhao, J. Wang, V. Mishra, S.I. Arbuzov, M. Zhang, 2020 CC BY-SA 
b). Most of the studies of palaeo-wildfires are related to the wildfires occurred in the Late Paleozoic era (Arzadún et al., 2017; Jasper et al., 2013; Kauffmann et al., 2016; Manfroi et al., 2015; Shen et al., 2011; Singh and Shukla, 2004; Sun et al., 2017). These palaeo-wildfires consumed $\mathrm{O}_{2}$ and released $\mathrm{CO}, \mathrm{CO}_{2}$ to the atmosphere which modified the atmospheric temperatures and ecosystems (Berner, 2006; Lenton, 2013; Scott and Glasspool, 2006; Scott et al., 2016). Sun et al. (2017) have reported also that the palaeowildfires of the Middle Permian could have discharged massive quantities of pollutants and increased the ambient temperature, causing the floral extinction that occurred at the Middle Permian. Shen et al. (2011) have reported also that the wildfires of the Late Permian may have acted as a catalyst to the Permo-Triassic Boundary (PTB) mass extinction events.

Although the palaeo-wildfires of the Late Permian in southern China have been studied by Shen et al. (2011), northern China is devoid of this kind of study as coal seams of this age are not present there and wildfire evidence are difficult to find in sedimentary rocks. The main purpose of this study is to examine the available sedimentary rocks from the northern China basin to search for pieces of evidence of the palaeo-wildfires in the Late Permian is. Findings of this investigation may be of relevance for the comprehension of the causes of the Permo-Triassic mass extinction. With this aim, 14 rock samples were collected from a drill core of Hanxing Coalfield and they were investigated through petrography (macro and micro), SEM, GC and GC-MS to characterize their organic structures and compounds.

\section{GEOLOGICAL SETTING}

Hanxing Coalfield was formed and developed in the center of the North China basin (Fig. 1), which belongs to the northern part of the Sino-Korean Craton (Zhao et al., 2006). The Late Paleozoic stratigraphic records geological setting of the North China basin has been reviewed by Stevens et al. (2011), Sun et al. (2002, 2017) and Wang and Pfefferkorn (2013) in detail. The North China basin is surrounded by the Central Asian Orogenic Belt and

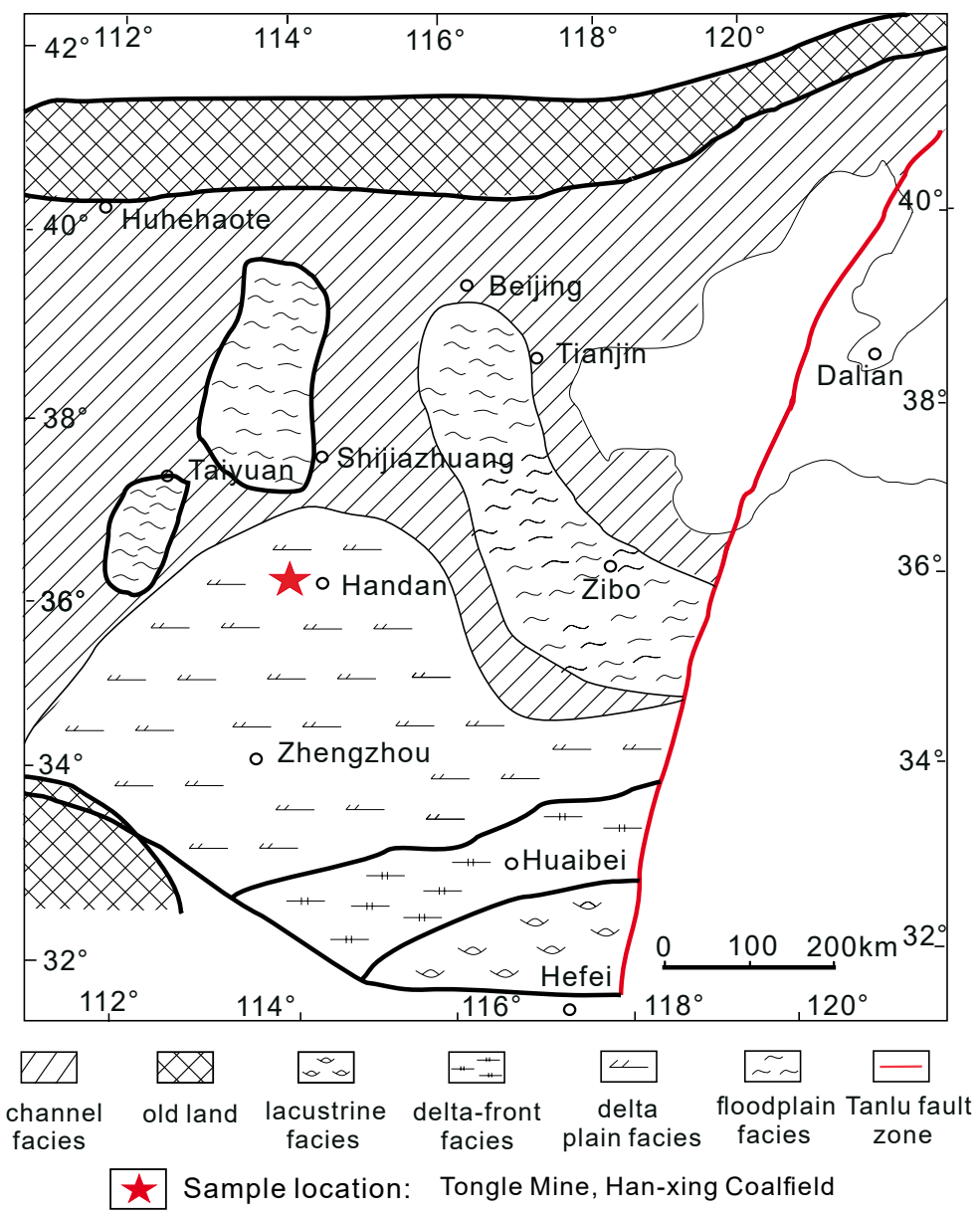

FIGURE 1. Palaeogeographic map of the study are of North China basin (Modified from Sun et al., 2017). 
Qinling-Dabie-Sulu Orogens. The oldest, pre-orogeny strata of this basin are Cambrian in age and consists of marine sediments, including grey quartz sandstones, dolomites, shales, limestones and marls. Seawater covered the entire basin during the Cambrian period.

The basement rocks of the Hanxing Coalfield are dated to the Early to Middle Ordovician, and mostly consist of epicontinental carbonate sediments. Sediments from Late Ordovician, Silurian, Devonian and part of the Early Carboniferous are absent because of the uplift of the North China basin during the Early Paleozoic to early Late Paleozoic. The Late Carboniferous sediments were deposited in paralic environments and consisted of siltstone and claystone (Li et al., 2010; Stevens et al., 2011; Yang et al., 2017). The Taiyuan and Shanxi formations are coal-bearing units of Early Permian and earlier Middle Permian age respectively (Fig. 2). The Taiyuan Formation was deposited in a predominantly paralic environment and the sediments mainly consist of siltstone and coal seams. The Shanxi Formation was deposited in a fluvial-dominated deltaic depositional environment and the sediments mainly consist of mudstone, siltstone and coal seams (Sun et al., 2017; Wang et al., 2019).
The Upper Permian consists of the Lower and Upper Shihhotse formations, and the overlying Shiqianfeng Formation. These formations were dominated by alluvial sandstones, siltstones and clays, and a certain amount of coal with abundant plant fossils. The Lower Shihhotse Formation are dominated by grey sandstones, brown-green homogeneous siltstones and clays. The Upper Shihhotse Formation is of similar composition but with a higher proportion of yellow laminated clays. The Shiqianfeng Formation lies unconformably above the Upper Shihhotse Formation (Hu et al., 1990; Wang, 2010), and is characterized by red to brown claystones interpreted as evidence of arid conditions (Stevens et al., 2011).

\section{SAMPLES AND METHODS}

All the analyses of the present study were carried out in the Key Laboratory of Resource Exploration Research of Hebei Province of Hebei University of Engineering, Handan, China.

\section{Sampling}

A total of fourteen (14) rock samples were collected from a drill core (No. 1204), embracing the sedimentary

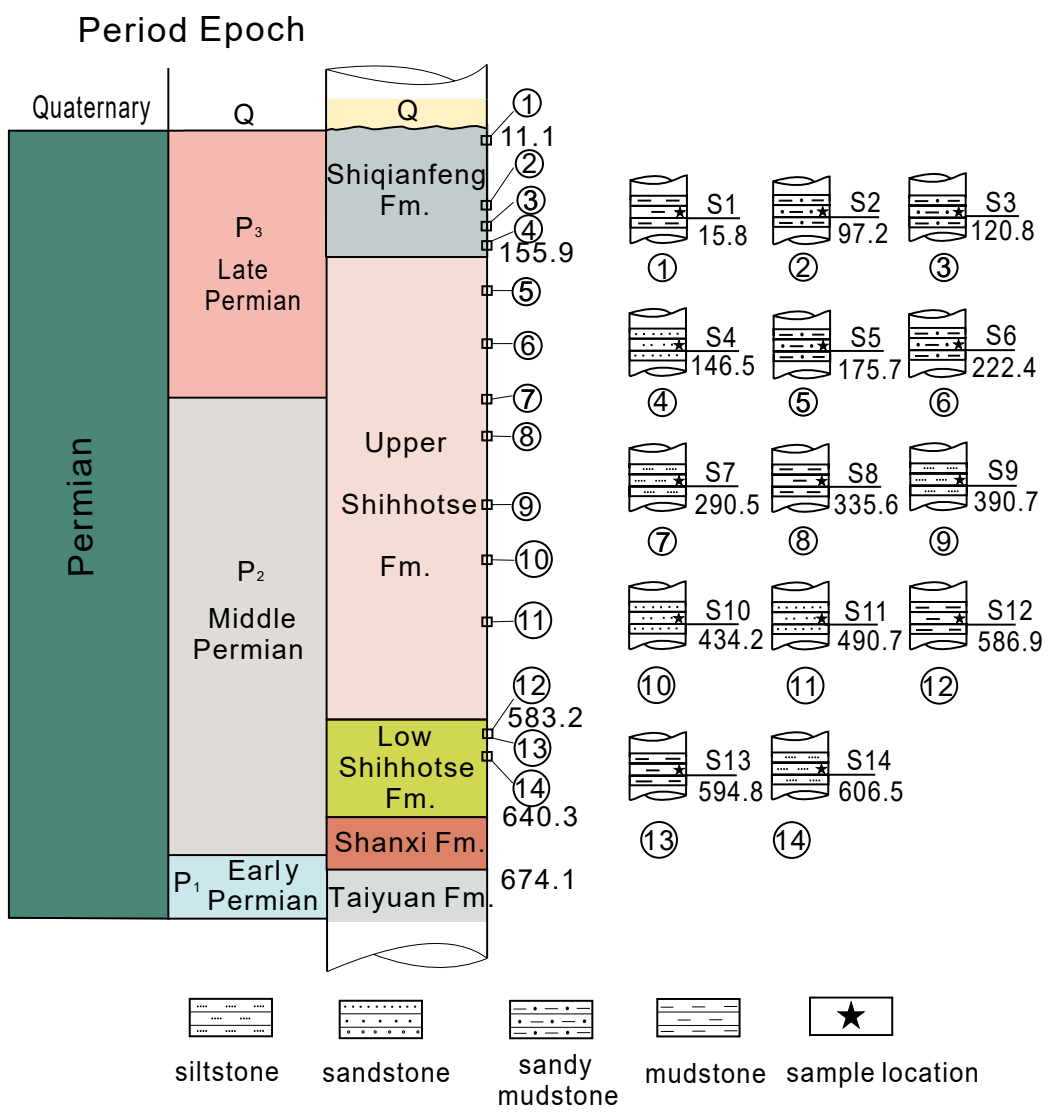

FIGURE 2. Stratigraphic succession of the Upper and Middle Permian period in the North China basin (modified after NCSC, 2014). 
sequences of the upper Middle and Late Permian in the Tongle mine, Hanxing Coalfield, northern China basin. Eight samples belong to the upper Middle Permian and six to the Late Permian (Fig. 2). Four samples were from the Shiqianfeng Formation, spanning an interval close to the PTB.

\section{Petrographic analysis}

For reflected light microscopy or organic petrography analysis, the samples were crushed to a size less than 20mesh. These fractions were embedded in epoxy resins, and the epoxy pellets were grounded and polished to obtain a smooth surface (Petersen and Lindström, 2012). Charcoal particles were investigated under a Leica DM2500P polarised light microscope, equipped with a Craic QDI 302 ${ }^{\mathrm{TM}}$ spectrophotometer. Vitrinite reflectance $\left(\mathrm{R}_{\mathrm{o}}\right)$ was also measured under Leica DM2500P reflected light microscope that was fitted with a halogen lamp. The measurement was calibrated using a Leitz glass standard $\left(\mathrm{R}_{\mathrm{oil}}=0.89 \%\right)$.

\section{FE-SEM analysis}

A Field-Emission-Scanning Electron Microscope (HITACHI UHR FE-SEM, SU8220), in conjunction with an EDAX energy-dispersive X-ray spectrometer (Genesis Apex 4), was used to study the morphology of the minerals and determine the distribution of some elements. The coal samples were coated with conductive carbon materials and were analyzed at a working distance of $10 \mathrm{~mm}$, a beam voltage of $20.0 \mathrm{kV}$, an aperture of 6 , and a spot size of grade 5.0. The images were captured via a retractable solid-state backscatter electron detector. The experimental methods were performed following Sun et al. (2017).

\section{Solvent extraction and liquid chromatography}

For organic geochemical analyses, samples were solventextracted for $48 \mathrm{~h}$ using chloroform as solvent. Extract yields were determined gravimetrically after removal of the solvent. The extracts were separated into three fractions (saturated hydrocarbons, aromatic hydrocarbons and NSOcompounds) by column chromatography over pre-washed silica gel (70-230mesh, 50-1cm). The alkanes were eluted with n-hexane, the aromatic hydrocarbons and aromatic sulfur compounds with dichloromethane, and the polar compounds (hetero-compounds) with methanol $(40 \mathrm{ml}$ for each fraction).

\section{Gas Chromatography-Mass Spectrometry}

GC and GC-MS analyses of the aromatic fractions were performed on a Hewlett-Packard model 6890 GC coupled to a Hewlett-Packard model 5973 quadrupole Mass
Spectrometric Detection (MSD). Squalane has been added to the aromatic hydrocarbon fractions as internal standards prior to analysis. GC separation was achieved on a fused silica capillary column coated with DB5 $(30 \mathrm{~m} \times 0.25 \mathrm{~mm}$ i.d., $0.25 \mu \mathrm{m}$ film thickness). The $\mathrm{GC}$ operating conditions were performed through three steps: temperature held at $60^{\circ}$ for $5 \mathrm{~min}$, increased from 60 to $300^{\circ}$ at a rate of $4^{\circ} \mathrm{C} \mathrm{min}{ }^{-1}$ with final isothermal hold at $300^{\circ} \mathrm{C}$ for $15 \mathrm{~min}$. Helium was used as a carrier gas. The sample was injected at a split ratio of $30: 1$ with the injector temperature at $290^{\circ} \mathrm{C}$. The mass spectrometer was operated in an electron impact mode at $70 \mathrm{eV}$ and scanned from 50 to 650Da. Data were acquired and processed with Chemstation software. Individual compounds were identified through comparisons of mass spectra with available pieces of literature and library data, along with interpretations of mass spectrometric fragmentation patterns.

\section{RESULTS AND DISCUSSION}

\section{Charcoal particles}

Many paleoecologists, palaeobotanists and palaeoclimatologists defined most wildfire products as charcoal (including inertinite and natural char (sensu International Committee for Coal and Organic Petrology (ICCP), see Kwiecińska and Petersen, 2004), which is referred as inertinite in the petrography study of coals (Robson et al., 2015; Scott, 2010; Sýkorová et al., 2005). In this study, the term inertinite is used following the definition of ICCP (2001), and the term charcoal following the definition of Scott (2010).

Abundant charcoal particles were observed on the drill core samples (Fig. 3). Through naked eyes these particles were dark in color, irregular shaped and distributed throughout the sediments. The particle sizes vary from several millimeters to several centimeters. Under the microscope, these charcoal particles show a prominent cellular structure with very high reflectivity (Fig. 4) and belong to the distinctive fusinite maceral (sensu ICCP). Kwiecińska and Petersen (2004) found that some particles have higher reflectance than the associated inertinite macerals which are referred as natural char on the basis of the distribution of pores (Fig. 4).

About their genetic mechanisms, Kwiecińska and Petersen (2004) believed that "natural char is formed by the influence of heat from the fire on (1) coal or (2) gelified organic matter in peat". Glasspool and Scott (2013) stated that inertinite (fusinite) is synonymous of charcoal and is considered to be formed almost exclusively as a product of wildfires. Therefore, charcoal has been considered as the strongest evidence of palaeo-wildfires (Jasper et al., 2013; 


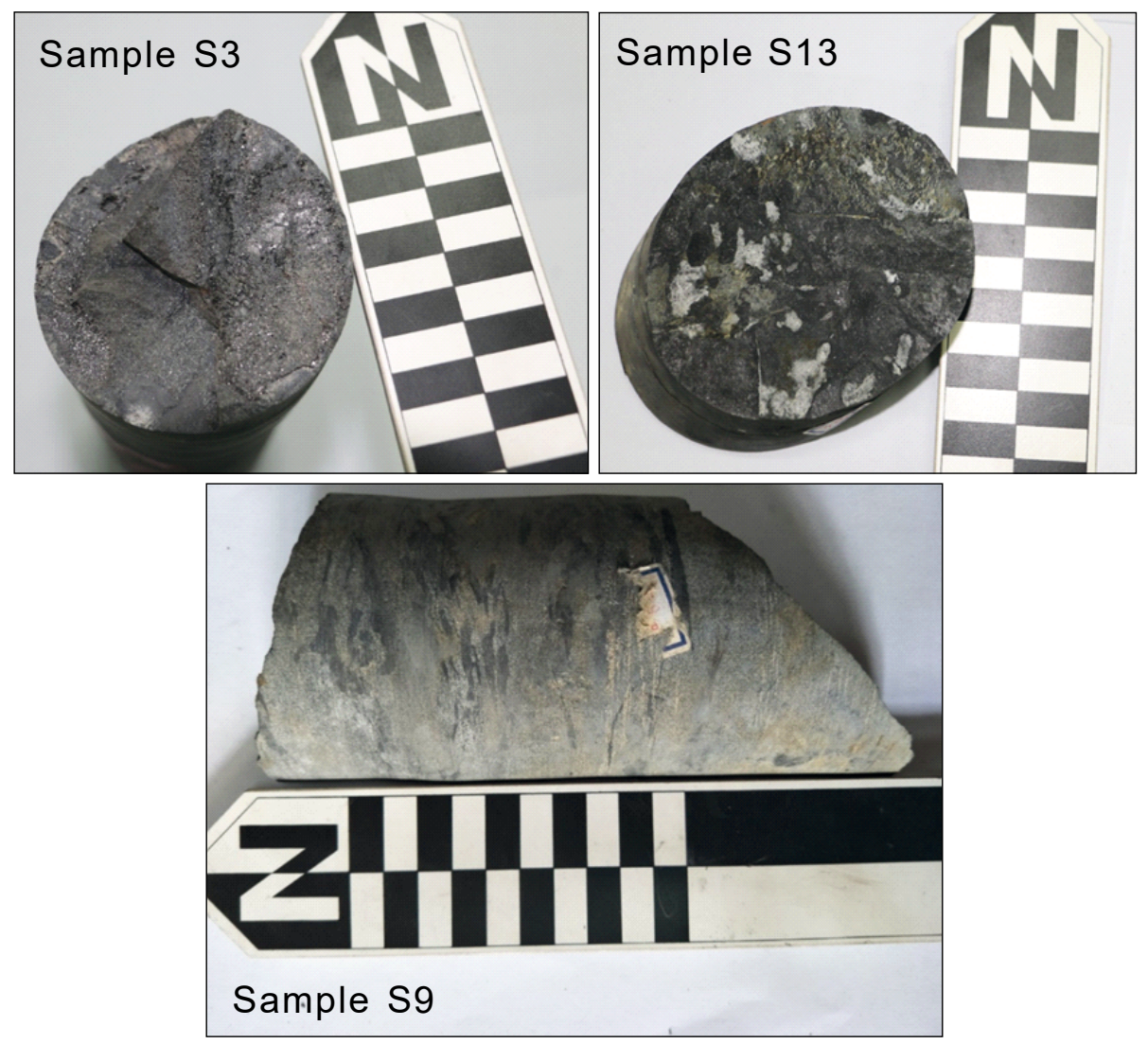

FIGURE 3. Charcoal particles in the drill core of the Upper and Middle Permian rocks from North China basin. Black/white scale in centimeters.

Kauffmann et al., 2016; Scott and Glasspool, 2006; Shen et al., 2011; Sun et al., 2017; Yan et al., 2019). The presence of abundant charcoal particles in this study evidence that the palaeo-wildfires occurred in North China in the Late Permian.

Charcoal structure and their reflectivity were studied here because the wildfire type and its burning temperature can be deduced from the charcoal shape and reflectivity (Scott, 2010). Under the electron microscope, wood cell walls displayed both lamellar and homogenous aspect (Fig. 5) that confirmed the material as charcoal (DeganiSchmidt et al., 2015). According to Scott (2010), the cell walls of charcoal would homogenize at $>300-325^{\circ} \mathrm{C}$ and fragmented at $>600^{\circ} \mathrm{C}$. In this study, some cell walls of charcoal observed under SEM show a homogeneous aspect indicating that the combustion temperature of wildfire was $>300-325^{\circ} \mathrm{C}$. Crashed cell walls were also observed indicating that these fragmented charcoal particles could have formed at a temperature above $600^{\circ} \mathrm{C}$ (Fig. 5).

The reflectance of charcoal is also related to the burning temperature showing a positive relationship between them (Ascough et al., 2010; Guo and Bustin, 1998; Scott, 2010;
Scott and Glasspool, 2005). According to Petersen and Lindström (2012), the burning temperature of wildfire can be roughly calculated by the following equation:

$\mathrm{T}=184.10+117.76 \times \%$ Ro $\left(\mathrm{r}^{2}=0.91\right)$

where $\mathrm{T}$ is the burning temperature and $\% \mathrm{R}_{\mathrm{o}}$ is the measured inertinite reflectance.

The reflectance of the charcoal particles from the Hanxing coal here analyzed varies from $3.12 \%$ to $4.84 \%$ and, according to the above equation, it formed in a temperature range from $552^{\circ} \mathrm{C}$ to $754^{\circ} \mathrm{C}$.

Thus, here we get two sets of temperatures derived from the samples' morphology $\left(>300-325^{\circ} \mathrm{C}\right)$ and reflectance $\left(552-754^{\circ} \mathrm{C}\right)$. Wildfires can be characterized by different burning temperatures and according to that, they can be grouped into ground fires, surface fires, and crown fires. The temperature of a ground fire is generally lower than $350^{\circ} \mathrm{C}$, while the temperature of a surface fire is generally between $300^{\circ} \mathrm{C}$ and $700^{\circ} \mathrm{C}$. The temperature of a crown fire is higher and can reach $1000^{\circ} \mathrm{C}$ (Petersen and Lindström, 2012; Scott and Jones, 1994). Therefore, it can be speculated that wildfires occurred in the Late Permian belong to surface and crown fires. 

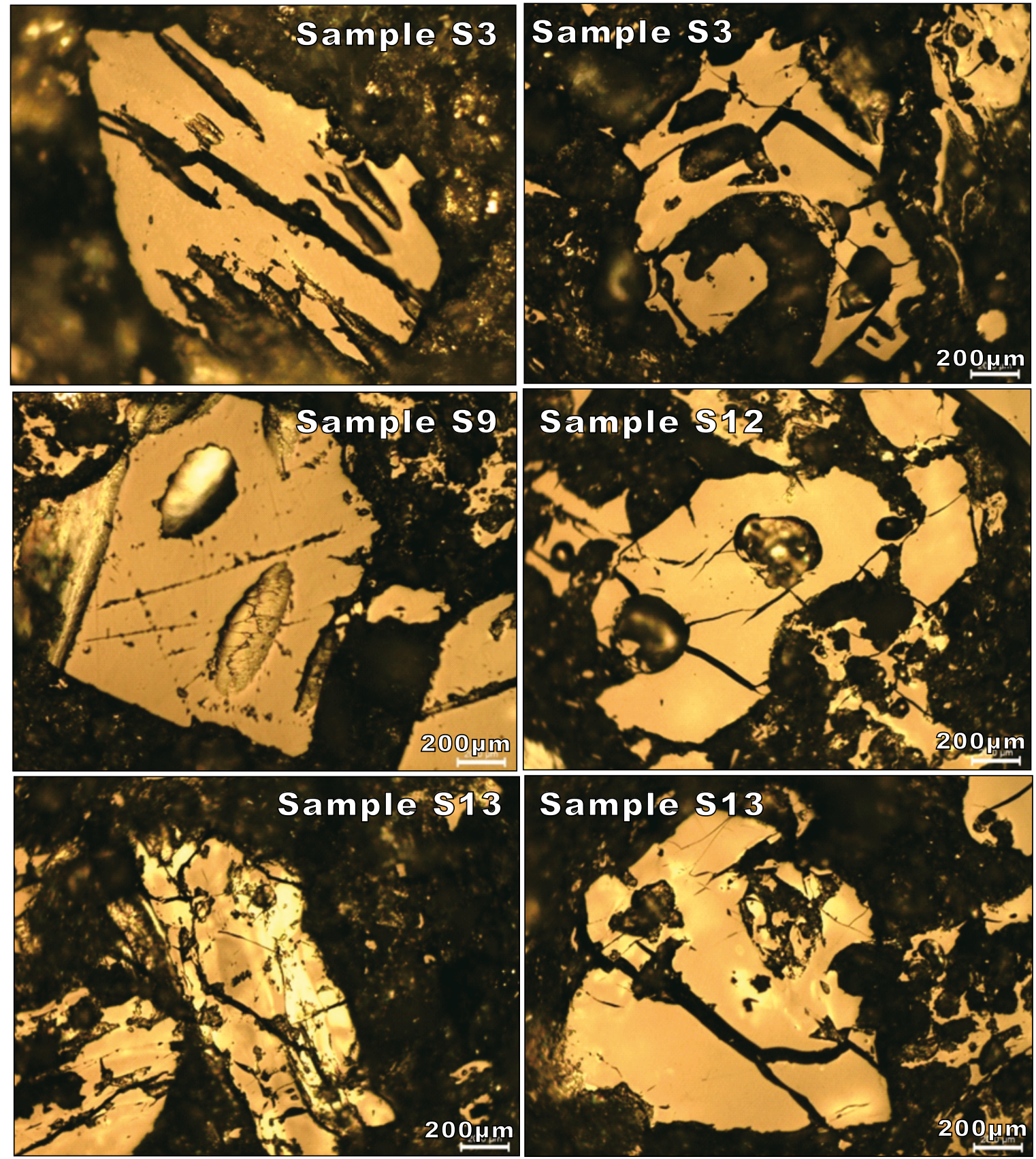

FIGURE 4. Photomicrographs of the charcoal particles in the Upper and Middle Permian sedimentary rocks from North China basin.

\section{Polycyclic Aromatic Hydrocarbons (PAHs)}

A total number of 16 PAHs with 4-6 rings were detected in most of the samples (Figure 6; Table 1), such as fluoranthene (Fla), pyrene (Py), methylfluoranthene (MFla), benz[a]anthracene(BaAn), chrysene/ triphenylene (Chry + Tpn, hereafter referred to as Chry in the text), methylchrysene (Mchry), benzo[a] pyrene (BePy), benzo[e]pyrene (BaPy), perylene (Pery), indeno[1,2,3-cd]pyrene (InPy), benzo[ghi] perylene (BghiP). The typical distribution of PAHs in the samples is presented in Figure 6.

There are two main sources of PAHs in sedimentary strata i.e. incomplete combustion of vegetation or fossil fuels and degradation of organic matter by microorganisms during diagenesis (Hossain et al., 2013; Meng et al., 2019). PAHs derived from combustion mainly produce $>4$ ring PAHs, while diagenetic PAHs often have 2-4 rings (Denis et al., 2012; Sun et al., 2017). The PAHs 

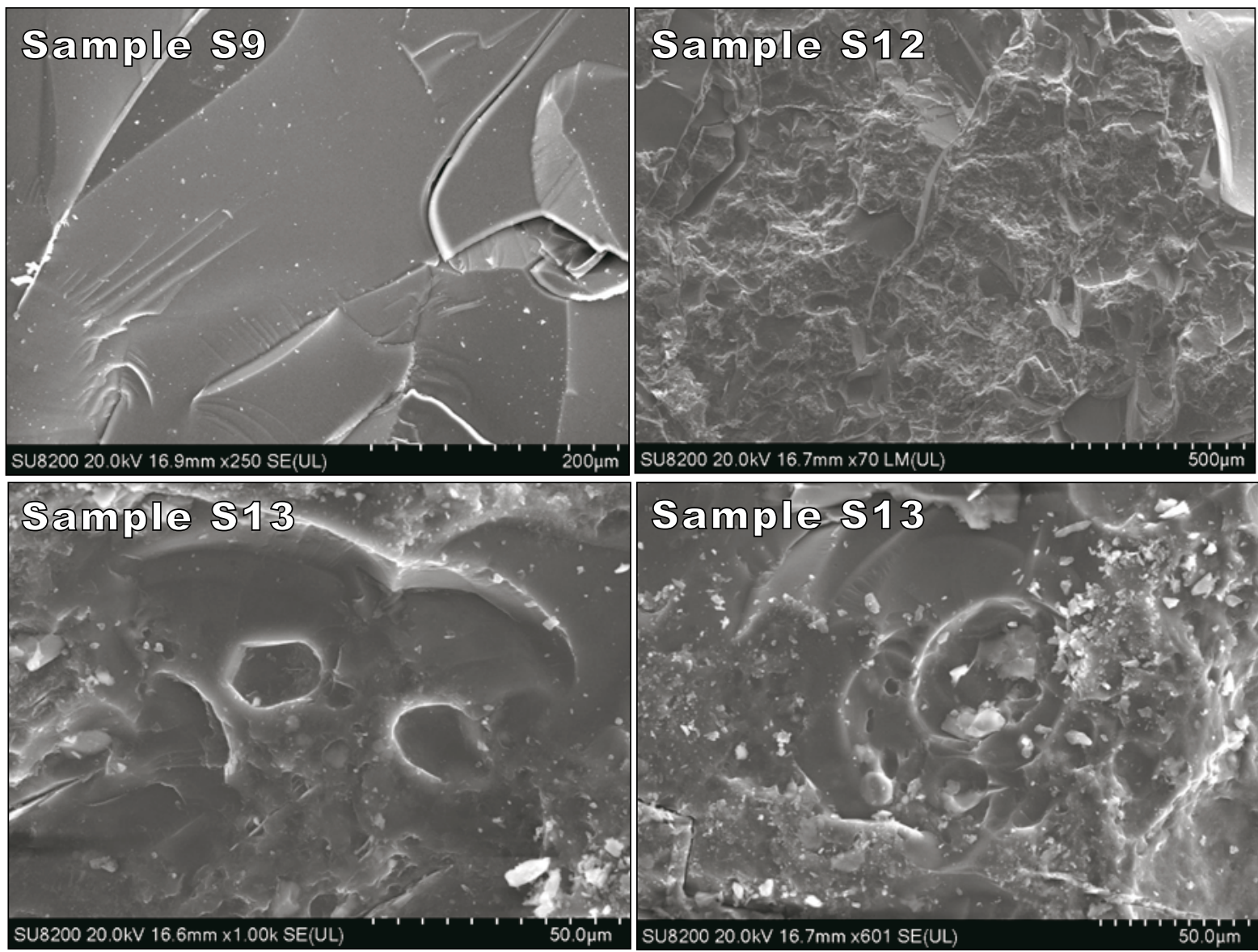

FIGURE 5. SEM photographs of the charcoal particles from North China basin.

originally formed by combustion may be alkylated during diagenesis, and those susceptible PAHs may disappear during this process (Denis et al., 2012; Hossain et al., 2013; Jiang et al., 1998). The higher the number of aromatic rings, the stronger the antioxidant ability of PAHs. Therefore, PAHs with 5-6 rings are less likely to be affected during diagenesis (Denis et al., 2012). Studies show that BePy is the most stable PAH among the 5-ring PAHs (Jiang et al., 1998; Sullivan et al., 1989). BghiP (5-ring) generally originated through combustion and had been reported from high intensity paleo vegetation fires (Denis et al., 2012; Hossain et al., 2013; Jiang et al., 1998). Therefore, identified PAHs with 5-6 rings in this study should be formed by pyrogenic activity. Because there is no volcanic activity in the area, the occurrence of pyrogenic PAHs indicates that a wide range of ancient wildfires occurred in North China basin during the Middle and Late Permian, and the abundance of $>4$ ring PAHs in the top three samples (S1-S3) indicate that wildfires could have occurred in the P-T boundary. Samples S4 and S5 are devoid of $>4$ ring PAHs indicating absence of wildfire or absence of vegetation at that time.
Compounds produced at different combustion temperatures are different. The higher the combustion temperature is, the likelier are PAHs with more than 5 rings to be produced (Finkelstein et al., 2005; Hossain et al., 2013). Therefore, PAHs with low molecular weight (Fla, Chry, etc.) mostly indicate low temperature fire like in samples S10, S11, S12 and S14, while PAHs with high molecular weight (BePy, BaPy, InPy and Bpery) generally indicate high temperature fire like in Samples S2, S3, S6-S9 and S13 (Denis et al., 2012; Hossain et al., 2013).

\section{Possible influences of the wildfire}

It is generally accepted that the release of pollutants such as sulphur dioxide and toxic compounds such as the polycyclic aromatic hydrocarbons by wildfire could have influenced paleoclimate and palaeoecosystem (Scott and Jones, 1994; Van de Schootbrugge et al., 2009; Xu et al., 2020a, b). Shen et al. (2011) studied widespread wildfires close to PTB in South China and believed that wildfire, along with fire-derived products, could have been one of the reasons for the PTB mass extinction. The charcoal particles of this study indicate wildfires occurred not 

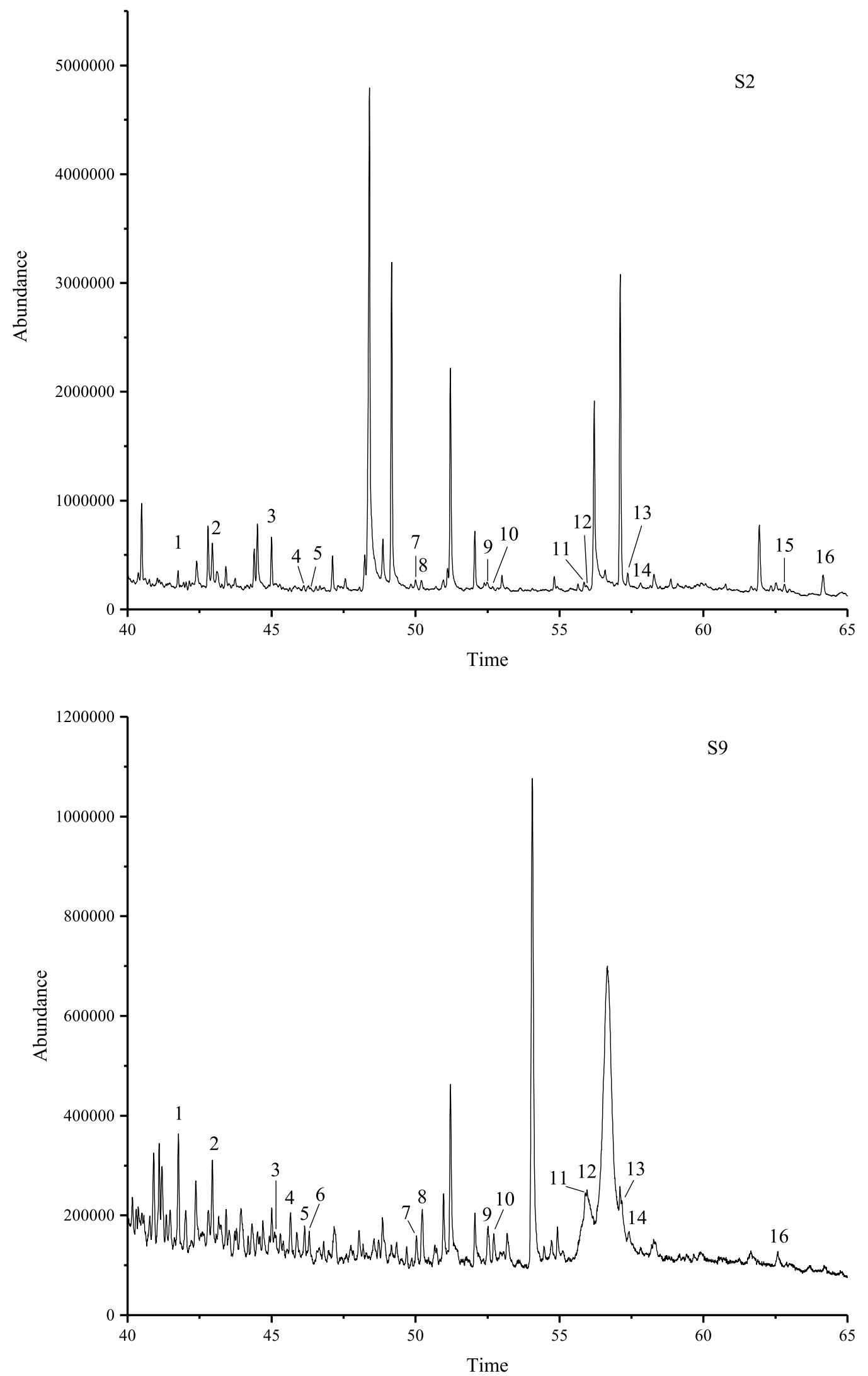

FIGURE 6. Gas chromatograms of aromatic hydrocarbon fractions of the Upper and Middle Permian samples. For assignment of peak numbers to individual compounds, see Table 1. 
TABLE 1. Identified four-, five- and six-ring PAHs of the Upper and Middle Permian rock samples from Hanxing Coalfield, North China Basin

\begin{tabular}{|c|c|c|c|c|c|c|c|c|c|c|c|c|c|c|c|c|c|}
\hline \multirow{2}{*}{$\begin{array}{l}\text { Compound } \\
\text { No. }\end{array}$} & \multirow{2}{*}{ Compound name } & \multirow{2}{*}{$\mathrm{m} / \mathrm{z}$} & \multicolumn{14}{|c|}{ Sample No. } & \multirow{2}{*}{ Molecular structure } \\
\hline & & & S1 & $\mathrm{S} 2$ & S3 & S4 & S5 & S6 & S7 & S8 & S9 & S10 & S11 & S12 & $\mathrm{S} 13$ & S14 & \\
\hline 1 & fluoranthene & 202 & $\sqrt{ }$ & $\sqrt{ }$ & $\sqrt{ }$ & $x$ & $x$ & $\sqrt{ }$ & $\sqrt{ }$ & $\sqrt{ }$ & $\sqrt{ }$ & $\sqrt{ }$ & $\sqrt{ }$ & $\sqrt{ }$ & $\sqrt{ }$ & $\sqrt{ }$ & \\
\hline 2 & pyrene & 202 & $\sqrt{ }$ & $\sqrt{ }$ & $\sqrt{ }$ & $x$ & $x$ & $\sqrt{ }$ & $\sqrt{ }$ & $\sqrt{ }$ & $\sqrt{ }$ & $\sqrt{ }$ & $\sqrt{ }$ & $\sqrt{ }$ & $\sqrt{ }$ & $\sqrt{ }$ & \\
\hline 3 & methylfluoranthene & 216 & $\sqrt{ }$ & $\sqrt{ }$ & $\sqrt{ }$ & $x$ & $x$ & $\sqrt{ }$ & $\sqrt{ }$ & $\sqrt{ }$ & $\sqrt{ }$ & $x$ & $x$ & $\sqrt{ }$ & $\sqrt{ }$ & $\sqrt{ }$ & \\
\hline 4 & methylfluoranthene & 216 & $\sqrt{ }$ & $\sqrt{ }$ & $\sqrt{ }$ & $x$ & $x$ & $\sqrt{ }$ & $\sqrt{ }$ & $\sqrt{ }$ & $\sqrt{ }$ & $x$ & $x$ & $\sqrt{ }$ & $\sqrt{ }$ & $\sqrt{ }$ & \\
\hline 5 & methylfluoranthene & 216 & $\sqrt{ }$ & $\sqrt{ }$ & $\sqrt{ }$ & $x$ & $x$ & $\sqrt{ }$ & $\sqrt{ }$ & $\sqrt{ }$ & $\sqrt{ }$ & $x$ & $x$ & $\sqrt{ }$ & $\sqrt{ }$ & $\sqrt{ }$ & \\
\hline 6 & methylfluoranthene & 216 & $\sqrt{ }$ & $\sqrt{ }$ & $\sqrt{ }$ & $x$ & $x$ & $\sqrt{ }$ & $\sqrt{ }$ & $\sqrt{ }$ & $\sqrt{ }$ & $x$ & $x$ & $\sqrt{ }$ & $\sqrt{ }$ & $\sqrt{ }$ & \\
\hline 7 & benzo(a)anthracene & 228 & $\sqrt{ }$ & $\sqrt{ }$ & $\sqrt{ }$ & $x$ & $x$ & $\sqrt{ }$ & $\sqrt{ }$ & $\sqrt{ }$ & $\sqrt{ }$ & $\sqrt{ }$ & $x$ & $x$ & $\sqrt{ }$ & $x$ & \\
\hline 8 & triphenylene + chrysene & 228 & $\sqrt{ }$ & $\sqrt{ }$ & $\sqrt{ }$ & $x$ & $x$ & $\sqrt{ }$ & $\sqrt{ }$ & $\sqrt{ }$ & $\sqrt{ }$ & $\sqrt{ }$ & $x$ & $x$ & $\sqrt{ }$ & $x$ & \\
\hline 9 & methylchrysene & 242 & $x$ & $\sqrt{ }$ & $\sqrt{ }$ & $x$ & $x$ & $\sqrt{ }$ & $\sqrt{ }$ & $\sqrt{ }$ & $\sqrt{ }$ & $x$ & $x$ & $x$ & $\sqrt{ }$ & $x$ & \\
\hline 10 & methylchrysene & 242 & $x$ & $\sqrt{ }$ & $\sqrt{ }$ & $x$ & $x$ & $\sqrt{ }$ & $\sqrt{ }$ & $\sqrt{ }$ & $\sqrt{ }$ & $x$ & $x$ & $x$ & $\sqrt{ }$ & $x$ & \\
\hline 11 & $\begin{array}{l}\text { benzo(k)fluoranthene }+ \\
\text { benzo(b)fluoranthene }\end{array}$ & 252 & $x$ & $\sqrt{ }$ & $\sqrt{ }$ & $x$ & $x$ & $\sqrt{ }$ & $\sqrt{ }$ & $\sqrt{ }$ & $\sqrt{ }$ & $x$ & $x$ & $x$ & $\sqrt{ }$ & $x$ & \\
\hline 12 & benzo(a)pyrene & 252 & $\times$ & $\sqrt{ }$ & $\sqrt{ }$ & $x$ & $x$ & $\sqrt{ }$ & $\sqrt{ }$ & $\sqrt{ }$ & $\sqrt{ }$ & $x$ & $x$ & $x$ & $\sqrt{ }$ & $x$ & \\
\hline 13 & benzo(e)pyrene & 252 & $x$ & $\sqrt{ }$ & $\sqrt{ }$ & $x$ & $x$ & $\sqrt{ }$ & $\sqrt{ }$ & $x$ & $\sqrt{ }$ & $x$ & $x$ & $x$ & $\sqrt{ }$ & $x$ & \\
\hline 14 & perylene & 252 & $x$ & $\sqrt{ }$ & $\sqrt{ }$ & $x$ & $x$ & $\sqrt{ }$ & $\sqrt{ }$ & $x$ & $\sqrt{ }$ & $x$ & $x$ & $x$ & $\sqrt{ }$ & $x$ & \\
\hline 15 & indeo( $1,2,3$-cd)pyrene & 276 & $\times$ & $\sqrt{ }$ & $\sqrt{ }$ & $x$ & $x$ & $\sqrt{ }$ & $\sqrt{ }$ & $x$ & $\sqrt{ }$ & $x$ & $x$ & $x$ & $x$ & $x$ & \\
\hline 16 & benzo(ghi)perylene & 276 & $x$ & $\sqrt{ }$ & $\sqrt{ }$ & $x$ & $x$ & $\sqrt{ }$ & $\sqrt{ }$ & $\times$ & $\sqrt{ }$ & $x$ & $x$ & $x$ & $x$ & $x$ & \\
\hline
\end{tabular}

Explanation: $\sqrt{ }=$ detected, $x=$ non-detected

only in South China but also in North China basin during the Late Permian, with the other global wildfire events (Arzadún et al., 2017; Grasby et al., 2011; Kauffmann et al., 2016). These wildfires could have consumed enormous amounts of $\mathrm{O}_{2}$ from the atmosphere and also discharge massive quantities of pollutants causing the increase of the environmental temperature.

\section{CONCLUSIONS}

This is the first report of the occurrence of wildfire close to PTB in the North China Basin. Abundant charcoal particles were observed in the sedimentary rock samples from the Hanxing Coalfield, indicating that widely prevalent wildfires occurred in the Middle and Late Permian. The reflectance values of the charcoal reveal that the wildfires belong to surface and crown type fires. The presence of high molecular PAHs is another evidence of wildfires in the study area. The occurrence of 5 and 6 ring PAHs in the studied samples indicates that the wildfire events had high temperature and most likely were crown fires. These wildfires could have consumed $\mathrm{O}_{2}$ and discharged pollutants to the atmosphere being one of the factors that influenced the paleoclimate and palaeoecology in the Late Permian.

\section{ACKNOWLEDGMENTS}

This research was financially supported by the National Natural Science Foundation of China (No. 41872173). We are very grateful to Mr. Zheng Gao, Mr. Kuo Liu and Mr. Jiawei Zhang for their kind support during sampling and laboratory work.

\section{REFERENCES}

Ascough, P.L., Bird, M.I., Scott, A.C., Collinson, M.E., CohenOfri, I., Snape, C.E., Le Manquais, K., 2010. Charcoal 
reflectance measurements: implications for structural characterization and assessment of diagenetic alteration. Journal of Archaeological Science, 37, 1590-1599.

Arzadún, G., Cisternas, M.E., Cesaretti, N.N., Tomezzoli, R.N., 2017. Presence of charcoal as evidence of paleofires in the Claromecó Basin, Permian of Gondwana, Argentina: Diagenetic and paleoenvironment analysis based on coal petrography studies. GeoResJ, 14, 121-134.

Berner, R.A., 2006. GEOCARBSULF: a combined model for Phanerozoic atmospheric $\mathrm{O}_{2}$ and $\mathrm{CO}_{2}$. Geochimica et Cosmochimica Acta, 70, 5653-5664.

Degani-Schmidt, I., Guerra-Sommer, M., de Oliveira Mendonça, J., Mendonça Filho, J.G., Jasper, A., Cazzulo-Klepzig, M., Iannuzzi, R., 2015. Charcoalified logs as evidence of hypautochthonous/ autochthonous wildfire events in a peat-forming environment from the Permian of southern Paraná Basin (Brazil). International Journal of Coal Geology, 146, 55-67.

Denis, E.H., Toney, J.L., Tarozo, R., Anderson, R.S., Roach, L.D., Huang, Y., 2012. Polycyclic aromatic hydrocarbons (PAHs) in lake sediments record historic fire events: validation using HPLC-fluorescence detection. Organic Geochemistry, 45, 7-17.

Finkelstein, D.B., Pratt, L.M., Curtin, T.M., Brassell, S.C., 2005. Wildfires and seasonal aridity recorded in Late Cretaceous strata from south - eastern Arizona, USA. Sedimentology, 52, 587-599.

Flannigan, M.D., Krawchuk, M.A., de Groot, W.J., Wotton, B.M., Gowman, L.M., 2009. Implications of changing climate for global wildland fire. International journal of wildland fire, 18 , 483-507.

Freeman, D.J., Cattell, F.C.R., 1990. Woodburning as a source of atmospheric polycyclic aromatic hydrocarbons. Environmental Science \& Technology, 24, 1581-1585.

Glasspool, I.J., Scott, A.C., 2013. Identifying past fire events. In: Belcher, C.M. (eds.). Fire phenomena and the Earth system: An interdisciplinary guide to fire science. Oxford, John Wiley \& Sons, 179-206.

Grasby, S.E., Sanei, H., Beauchamp, B., 2011. Catastrophic dispersion of coal fly ash into oceans during the latest Permian extinction. Nature Geoscience, 4, 104-107.

Guo, Y., Bustin, R.M., 1998. FTIR spectroscopy and reflectance of modern charcoals and fungal decayed woods: implications for studies of inertinite in coals. International Journal of Coal Geology, 37, 29-53.

Hossain, H.Z., Sampei, Y., Roser, B.P., 2013. Polycyclic aromatic hydrocarbons (PAHs) in late Eocene to early Pleistocene mudstones of the Sylhet succession, NE Bengal Basin, Bangladesh: Implications for source and paleoclimate conditions during Himalayan uplift. Organic geochemistry, 56, 25-39.

Hu, S.R., Gao, W.T., Liu, H., 1990. The discovery of the plane of unconformity under bottom surface of Pingdingshan sandstone and the preliminary discussion about the boundary of the Permian-Triassic system, Henan Province (in Chinese). Coal Geology and Exploration, 4, 12-15.
ICCP, 2001. The new inertinite classification, International Committee for Coal and Organic Petrology (ICCP) System 1994. Fuel, 80, 459-471.

Jasper, A., Guerra-Sommer, M., Hamad, A.M.B.A., Bamford, M., Bernardes-de-Oliveira, M.E.C., Tewari, R., Uhl, D., 2013. The burning of Gondwana: Permian fires on the southern continent - a palaeobotanical approach. Gondwana Research, 24, 148-160.

Jiang, C., Alexander, R., Kagi, R.I., Murray, A.P., 1998. Polycyclic aromatic hydrocarbons in ancient sediments and their relationships to palaeoclimate. Organic Geochemistry, 29, 1721-1735.

Kauffmann, M., Jasper, A., Uhl, D., Meneghini, J., Osterkamp, I.C., Zvirtes, G., Pires, E.F., 2016. Evidence for palaeowildfire in the Late Permian palaeotropics-Charcoal from the Motuca Formation in the Parnaíba Basin, Brazil. Palaeogeography, palaeoclimatology, palaeoecology, 450, 122-128.

Kwiecińska, B.K., Petersen, H.I., 2004. Graphite, semi-graphite, natural coke and natural char classification ICCP system. International Journal of Coal Geology, 57, 99-116.

Lenton, T.M., 2013. Fire feedbacks on atmospheric oxygen. In: Belcher, C.M. (eds.). Fire phenomena and the Earth system: An interdisciplinary guide to fire science. Oxford, John Wiley \& Sons, 289-308.

Li, H.Y., He, B., Xu, Y.G., Huang, X.L., 2010. U-Pb and Hf isotope analyses of detrital zircons from Late Paleozoic sediments: Insights into interactions of the North China Craton with surrounding plates. Journal of Asian Earth Sciences, 39, 335-346.

Manfroi, J., Uhl, D., Guerra-Sommer, M., Francischini, H., Martinelli, A.G., Soares, M.B., Jasper, A., 2015. Extending the database of permian palaeo-wildfire on Gondwana: charcoal remains from the Rio do Rasto Formation (Paraná Basin), middle permian, Rio Grande do Sul State, Brazil. Palaeogeography, palaeoclimatology, palaeoecology, 436, 77-84.

Meng, Y., Liu, X., Lu, S., Zhang, T., Jin, B., Wang, Q., Tang, Z., Liu, Y., Guo, X., Zhou, J., Xi, B., 2019. A review on occurrence and risk of polycyclic aromatic hydrocarbons (PAHs) in lakes of China. Science of The Total Environment, 651, 2497-2506.

National Commission of Stratigraphy of China (NCSC), 2014. The geologic time scale of China. Beijing, Geology Press, $1 \mathrm{pp}$.

Petersen, H.I., Lindström, S., 2012. Synchronous wildfire activity rise and mire deforestation at the Triassic-Jurassic boundary. PLoS One 7, e47236. https://doi.org/10.1371/journal. pone. 0047236

Robson, B.E., Collinson, M.E., Riegel, W., Wilde, V., Scott, A.C., Pancost, R.D., 2015. Early Paleogene wildfires in peat-forming environments at Schöningen, Germany. Palaeogeography, Palaeoclimatology, Palaeoecology, 437, 53-62.

Scott, A.C., Jones, T.P., 1994. The nature and influence of fire in Carboniferous ecosystems. Palaeogeography, Palaeoclimatology, Palaeoecology, 106, 91-112. 
Scott, A.C., Glasspool, I.J., 2005. Charcoal reflectance as a proxy for the emplacement temperature of pyroclastic flow deposits. Geology, 33, 589-592.

Scott, A.C., Glasspool, I.J., 2006. The diversification of Paleozoic fire systems and fluctuations in atmospheric oxygen concentration. Proceedings of the National Academy of Sciences, 103, 10861-10865.

Scott, A.C., 2010. Charcoal recognition, taphonomy and uses in palaeoenvironmental analysis. Palaeogeography, Palaeoclimatology, Palaeoecology, 291, 11-39.

Scott, A.C., Chaloner, W.G., Belcher, C.M., Roos, C.I., 2016. The interaction of fire and mankind: Introduction. Philosophical Transactions of the Royal Society B, 371, 20150162. https:// doi.org/10.1098/rstb.2015.0162

Shen, W., Sun, Y., Lin, Y., Liu, D., Chai, P., 2011. Evidence for wildfire in the Meishan section and implications for PermianTriassic events. Geochimica et Cosmochimica Acta, 75, 19922006.

Singh, M.P., Shukla, R.R., 2004. Petrographic characteristics and depositional conditions of Permian coals of Pench, Kanhan and Tawa Valley Coalfields of Satpura Basin, Madhya Pradesh, India. International Journal of Coal Geology, 59, 209-243.

Stevens, L.G., Hilton, J., Bond, D.P.G, Glasspool, I.J., Jardine, P.E., 2011. Radiation and extinction patterns in Permian floras from North China as indicators for environmental and climate change. Journal of the Geological Society, 168, 607-619.

Sullivan, R.F., Boduszynski, M.M., Fetzer, J.C., 1989. Molecular transformations in hydrotreating and hydrocracking. Energy \& Fuels, 3, 603-612.

Sun, Y., Püttmann, W., Kalkreuth, W., Horsfield, B., 2002. Petrologic and geochemical characteristics of seam 9-3 and seam 2, Xingtai Coalfield, Northern China. International Journal of Coal Geology, 49, 251-262.

Sun, Y., Zhao, C., Püttmann, W., Kalkreuth, W., Qin, S., 2017. Evidence of widespread wildfires in a coal seam from the middle Permian of the North China Basin. Lithosphere, 9, 595-608.

Sýkorová, I., Pickel, W., Christanis, K., Wolf, M., Taylor, G.H., Flores, D., 2005. Classification of huminite-ICCP System 1994. International Journal of Coal Geology, 62, 85-106.
Van de Schootbrugge, B., Quan, T.M., Lindström, S., Püttmann, W., Heunisch, C., Pross, J., Fiebig, J., Petschick, R., Röhling, H.G., Richoz, S., Rosenthal, Y., Falkowski, P.G., 2009. Floral changes across the Triassic/Jurassic boundary linked to flood basalt volcanism. Nature Geoscience, 2, 589-594.

Wang, J., 2010. Late Paleozoic macrofloral assemblages from Weibei Coalfield, with reference to vegetational change through the Late Paleozoic Ice-age in the North China Block. International Journal of Coal Geology, 83, 292-317.

Wang, J., Pfefferkorn, H.W., 2013. The Carboniferous-Permian transition on the North China microcontinent-oceanic climate in the tropics. International Journal of Coal Geology, 119, 106-113.

Wang, J., Xiao, L., Li, P., Arbuzov, S.I., Ding, S., 2019. Occurrence mode of selected elements of coal in the Ordos Basin. Energy Exploration \& Exploitation, 37, 1680-1693.

Xu, Y., Uhl, D., Zhang, N., Zhao, C.L., Qin, S.J., Liang, H.D., Sun, Y.Z., 2020a. Evidence of widespread wildfires in coal seams from the Middle Jurassic of Northwest China and its impact on paleoclimate. Palaeogeography, Palaeoclimatology, Palaeoecology. DOI: https://doi.org/10.1016/j. paleo.2020.109819

Xu, Y., Zhang, N., Zhao, C.L., Liang, H.D., Sun, Y.Z., 2020 b. Wildfires in Jurassic coal seams from Ordos Basin and its impact on paleoclimate. Geology in China. http://kns.cnki. net/kcms/detail/11.1167.p.20200130.1929.004.html

Yan, Z., Shao, L., Glasspool, I.J., Wang, J., Wang, X., Wang, H., 2019. Frequent and intense fires in the final coals of the Paleozoic indicate elevated atmospheric oxygen levels at the onset of the End-Permian Mass Extinction Event. International Journal of Coal Geology, 207, 75-83.

Yang, W., Hu, S.R., Ma, S.M., 2017. The relationship of paleontology, palaeobotany and coal thickness of Taiyuan Formation, Late Carboniferous-Early Permian in Shanxi Province. World Journal of Engineering, 14(2), 139-144.

Zhao, G., Cao, L., Wilde, S.A., Sun, M., Choe, W.J., Li, S., 2006. Implications based on the first SHRIMP U-Pb zircon dating on Precambrian granitoid rocks in North Korea. Earth and Planetary Science Letters, 251, 365-379.

\section{Manuscript received May 2020 \\ revision accepted June 2020; \\ published Online August 2020.}

